EESTI NSV TEADUSTE AKADEEMIA TOIMETISED. 20. KÖIDE

KEEMIA * GEOLOOGIA. 1971, NR. 1

ИЗВЕСТИЯ АКАДЕМИИ НАУК ЭСТОНСКОИ ССР. ТОМ 20

ХимИя * ГЕОЛОГИЯ. 1971, № 1

удК $547.563 \cdot 542.92$

ХЕЛИ РАУДСЕПП, Х. РАУДСЕПП

\title{
ИССЛЕДОВАНИЕ ТЕРМИЧЕСКОЙ ДЕСТРУКЦИИ ПРОПИЛ- И БУТИЛФЕНОЛОВ В ПРИСУТСТВИИ ВОДЯНОГО ПАРА
}

Наши предыдущие сообщения по термической деструкции крезолов ['] и этилфенолов [2] подтвердили, что характер происходящих при деструкции реакций зависит от строения и расположения алкильной группы фенола.

Исследования $M$. Гоникберга и других [3, 4] показали, что при гомогенной деструктивной гидрогенизации алкилфенолов по мере увеличения числа атомов углерода в боковой цепи, процессы термического распада боковой цепи начинают все более превалировать над реакциями, приводящими к отрыву всего алкильного радикала от ароматического ядра. В условиях каталитических превращений этил-, пропил- и бутилфенолы в зависимости от использованного катализатора дают весьма разнообразные продукты $\left.{ }^{5-14}\right]$.

Термическая деструкция высших алкилфенолов сравнительно мало изучена. Поэтому представляет интерес исследование термической деструкции алкилфенолов, имеющих более длинную алкильную щепь. В настоящем сообщении приводим результаты исследования термической деструкции $o$-изопропилфенола, $o$-пропилфенола, смеси $o$ - и $n$-бутилфенолов в присутствин водяного пара.

Опыты деструкции алкилфенолов проведены в реакторе, состоящем из кварцевой трубы объемом 180 мл, обогреваемой электрическими печами. Аппаратура описана в предыдущих статьях [1, 15]. Опыты проводились при температурах 700 и $750{ }^{\circ} \mathrm{C}$. Фенолы дозировались в реактор со скоростью 0,4 2/мuн, а подогретый до температуры деструкции водяной пар - со скоростью 1,5 г/мин. Соответствующее молярное соотношение водяного пара и фенолов при опытах с пропилфенолами было равно $27: 1$ и при опытах с бутилфенолами $-31: 1$. Рассчитанное время контакта деструкции составляло 5,6 сек. Жидкие продукты реакции выделялись экстракцией этиловым эфиром и анализировались методом газожидкостной хроматографии. В качестве стационарных фаз использовались апиезон $L$ и силиконовый эластомер $E$-301 на хромосорбе, а при анализе нейтральных компонентов еще твин 80 на хромосорбе. Для идентификации отдельных индивидуальных соединений, образующихся при деструкции, кроме газохроматографического метода использовалась также ультрафиолетовая спектрография. Состав газов деструкции определялся при помощи газоанализатора ВТИ. Чнстота исходных фенолов проверялась методом газо-жидкостной хроматографии; содержание примесей не превышало $1-2 \%$. Использованная при опытах смесь бутилфенолов состояла из $22,3 \%$ o-бутилфенола и $77,7 \%$ n-бутилфенола. 
В табл. 1 приведены результаты выхода продуктов, образующихся при деструкции $o$-изопропилфенола, 0 -пропилфенола и смеси $o$ - и $n$-бутилфенолов при температурах 700 и $750^{\circ}$ в присутствии водяного пара. В табл. 2 приведены выходы индивидуальных соединений в продуктах деструкции в пересчете на прореагировавший фенол.

Таблица $I$

Выход продуктов, образовавшихся при термической деструкции $o$-изопропилфенола, o-пропилфенола и смеси $o$ - и $n$-бутилфенолов

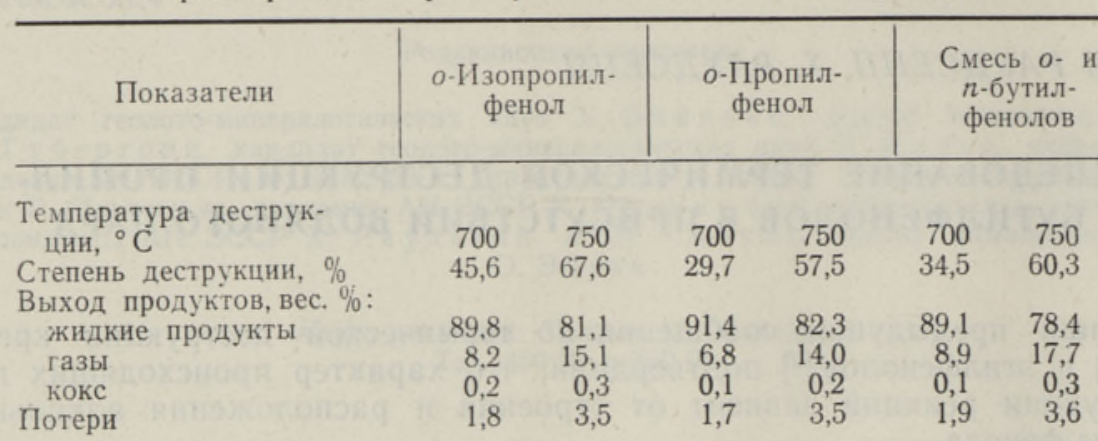

При ме ч ани е. Степень деструкции о-бутилфенола при $700^{\circ}-40,8 \%$, при $750^{\circ}-67,0 \%$; степень деструкции $n$-бутилфенола $-32,7$ и $59,3 \%$ соответственно.

Данные табл. 1, а также результаты наших предыдущих опытов $\left[{ }^{1,2}\right]$ показывают, что степень термической деструкции алкилфенолов зависит от длины, строения и расположения алкильной группы. Если при температуре $750^{\circ}$ степень деструкции $о$-метилфенола составляет $19,0 \%$ ['] и o-этилфенола - $52,6 \%\left[{ }^{2}\right]$, то степень деструкции о-пропилфенола $57,5 \%$ и $о$-бутилфенола - $67,0 \%$. о-Изопропилфенол является менее стабильным, чем $o$-пропилфенол. Степень деструкции $n$-изомеров алкилфенолов ниже, чем соответствующих $о$-изомеров.

Состав жидких продуктов деструкции показал, что при термической деструкции алкилфенолов образуются весьма разнообразные соединения. Протекающие при этом реакции можно разделить на следующие основные типы: 1) деструкция и отщепление алкильной группы, 2) отщепление гидроксильной группы, 3) циклизация алкильной группы с образованием метилиндена и индена, 4) циклизация алкильной группы, находящейся в 0 -положении, с образованием метилбензофурана и бензофурана, 5) деструкция ароматического ядра. Преобладают реакции, приводящие к деструкции алкильной группы. Главным продуктом реакции является крезол, выход которого составляет $35-46 \%$ на прореагировавший алкилфенол. Выход этилфенолов ниже и уменьшается с увеличением температуры деструкции. Следовательно, одновременно с реакциями деструкции боковой цепи исходного алкилфенола протекает и деструкция образовавшегося этилфенола. Пропилфенолы при деструкции бутилфенолов не образуются. Выход оксибензола составляет 11 $21 \%$ на прореагировавший алкилфенол. По-видимому, оксибензол является продуктом вторичных реакций. Свободные алкильные радикалы, возникающие при деструкции боковой цепи, преобразуются в непредельные углеводороды. Выход непредельных углеводородов тем выше, чем длиннее алкильная группа фенола. Предельные углеводороды состоят в основном из метана. 
Таблица 2

Выход продуктов деструкции $о$-изопропилфенола, 0 -пропилфенола и смеси o- и $n$-бутилфенолов в молярных процентах на прореагировавший фенол

\begin{tabular}{|c|c|c|c|c|c|c|}
\hline \multirow[b]{2}{*}{$\begin{array}{l}\text { Температура деструкции, } \\
{ }^{\circ} \mathrm{C}\end{array}$} & \multicolumn{2}{|c|}{$\begin{array}{l}\text { o-Изопропил- } \\
\text { фенол }\end{array}$} & \multicolumn{2}{|c|}{$\begin{array}{c}\text { o-Пропил- } \\
\text { фенол }\end{array}$} & \multicolumn{2}{|c|}{$\begin{array}{c}\text { Смесь o- и } \\
n \text {-бутил- } \\
\text { фенолов }\end{array}$} \\
\hline & 700 & 750 & 700 & 750 & 700 & 750 \\
\hline $\begin{array}{l}\text { Бензол } \\
\text { Толуол } \\
\text { Этилбензол } \\
\text { Изопропилбензол }\end{array}$ & $\begin{array}{l}0,7 \\
1,2 \\
0,5 \\
0,9\end{array}$ & $\begin{array}{l}1,0 \\
1,6 \\
0,5 \\
0,4\end{array}$ & $\begin{array}{r}1,6 \\
2,3 \\
1,2 \\
-\end{array}$ & $\begin{array}{l}2,0 \\
2,1 \\
0,6 \\
-\end{array}$ & $\begin{array}{l}2,0 \\
3,8 \\
1,5 \\
-\end{array}$ & $\begin{array}{l}2,3 \\
3,4 \\
0,9 \\
-\end{array}$ \\
\hline Пропилбензол & - & - & 0,7 & 0,2 & - & - \\
\hline Винилбензол & 1,0 & 1,4 & 0,8 & 1,1 & 3,4 & 3,6 \\
\hline Инден & 一 & 一 & 0,7 & 0,9 & 0,7 & 1,2 \\
\hline 3-Метилинден & $\overline{10}$ & $\overline{91}$ & $\overline{150}$ & $\overline{17}$ & 2.5 & 3,9 \\
\hline Бензофуран & 18,1 & 21,6 & 15,2 & 17,6 & 10,2 & 9,9 \\
\hline $\begin{array}{l}\text { 2-Метилбє } \\
\text { 3-Метилбе }\end{array}$ & $\overline{1,8}$ & $\overline{3}, 7$ & 2,9 & 1,2 & $\underline{4,1}$ & 2,2 \\
\hline Оксибензол & 11,4 & 13,9 & 17,8 & 21,0 & 15,2 & 16,6 \\
\hline o-Метилфенол & 46,2 & 36,0 & 38,4 & 35,5 & 12,9 & 10,3 \\
\hline n-Метилфенол & $\overline{0}_{7}$ & $\overline{50}_{0}$ & - & - 0 & 5,9 & 5,2 \\
\hline$o-Э$ тилфенол & 9,7 & 5,9 & 4,4 & 2,9 & $\begin{array}{l}7,0 \\
8 ?\end{array}$ & 3,8 \\
\hline енол & - & $\overline{-}$ & $\overline{0}_{0}$ & $\overline{0}_{0}$ & $\begin{array}{l}8,2 \\
0,9\end{array}$ & 6,5 \\
\hline $\begin{array}{l}0 \text {-1ропенилфенол } \\
n \text {-Пропенилфенол }\end{array}$ & - & - & - & - & 2,9 & $\begin{array}{l}0,9 \\
2,8\end{array}$ \\
\hline n-Изопропилфенол & 2,0 & 0,8 & - & - & - & - \\
\hline ифицированные & & & & & & \\
\hline $\begin{array}{l}\text { соединения } \\
\mathrm{CO}_{2}\end{array}$ & $\begin{array}{l}1,7 \\
2,3\end{array}$ & $\begin{array}{l}1,9 \\
4,8\end{array}$ & $\begin{array}{l}2,2 \\
4,1\end{array}$ & 5,1 & $\begin{array}{l}5,9 \\
5,2\end{array}$ & $\begin{array}{r}10,0 \\
6,7\end{array}$ \\
\hline & 11,4 & 19,7 & 20,0 & 27,5 & 23,1 & 35,8 \\
\hline $\mathrm{H}_{2}$ & 13,3 & 22,5 & 21,3 & 33,7 & 28,4 & 43,7 \\
\hline $\begin{array}{l}\mathrm{C}_{n} \mathrm{H}_{2 n} \\
\mathrm{C}_{n} \mathrm{H}_{2 n}\end{array}$ & $\begin{array}{l}50,1 \\
36,9\end{array}$ & $\begin{array}{l}51,5 \\
48,5\end{array}$ & $\begin{array}{l}60,7 \\
38,9\end{array}$ & $\begin{array}{l}54,3 \\
39,4\end{array}$ & $\begin{array}{l}67,4 \\
54,4\end{array}$ & $\begin{array}{l}70,7 \\
51,4\end{array}$ \\
\hline Кокс & 0 & 0, & 0 , & 0 & & 0,5 \\
\hline Потери & 5,7 & 6 , & 4,0 & 5,2 & 5,6 & 5,9 \\
\hline
\end{tabular}

Из вышеуказанного следует, что наименее устойчивой в боковой цепи пропилфенолов является связь между $\alpha$ - и $\beta$-атомами углерода. Разрыв $\beta-\gamma$ связи происходит незначительно. Те же самые закономерности наблюдаются и при распаде алкильной цепи бутилфенолов, хотя устойчивость $\beta-\gamma$ связи в бутильной группе меньше, чем в пропильной группе.

При деструкции пропил- и бутилфенолов образуются фенолы с алкенильной группой, из которых идентифицированы 0 - и $n$-пропенилфенолы, а также, несомненно, образуются и винилфенолы, но так как они очень легко полимеризуются $\left[{ }^{16}\right]$, их не удалось идентифицировать. Первым этапом образования алкенильных групп является разрыв C--H связи у $\alpha$-углеродного атома.

При термической деструкции алкилфенолов реакция дегидроксилирования протекает в меньшей степени. Общий выход производных бензола не превышает $10 \%$. При деструкции $o$-пропил-, $o$ - и $n$-бутилфенолов в незначительной степени происходит циклизация алкильной группы с образованием индена и 3-метилиндена соответственно.

При термической деструкции о-алкилфенолов протекает реакция дегидроциклизации с образованием бензофурана и его алкилпроизводных. Способность алкилфенолов к дегидроциклизации растет с повышением температуры деструкции. Бензофуран образуется и при деструкции $о$-этилфенола $\left[{ }^{2}\right]$. 
Образованием бензофурана и его производных при термической деструкции алкилфенолов объясняется содержание гидроксибензофуранов (гидроксикумаронов) в сланцевой смоле [17]. По всей вероятности, их присутствие связано с циклизацией, протекающей при деструкции боковых цепей двухатомных фенолов.

Данные табл. 2 показывают, что суммарный выход $\mathrm{CO}_{2}$ и $\mathrm{CO}$ превышает то количество, которое могло бы образоваться за счет кислорода гидроксильной группы. Следовательно, водяной пар участвует в реакциях, протекающих при деструкции фенолов. Видимо, свободные углеводородные радикалы, образующиеся при деструкции алкилфенолов, реагируют с водяным паром и образуют $\mathrm{CO}, \mathrm{CO}_{2}$ и $\mathrm{H}_{2}$.

\section{Выводы}

1. Изучена термическая деструкция 0 -пропилфенола, 0 -изопропилфенола и смеси 0 - и $n$-бутилфенолов в присутствии водяного пара при температурах 700 и $750^{\circ}$.

2. Степень деструкции алкилфенолов зависит от длины и строения боковой цепи и от ее расположения в ароматическом ядре.

3. Показано, что при термической деструкции алкилфенолов основной реакцией является распад боковой цепи с образованием низших фенолов.

4. Показано, что отщепление гидроксильной группы при термической деструкции алкилфенолов происходит в незначительной степени.

5. При термической деструкции $о$-алкилфенолов происходит дегидроциклизация с образованием бензофурана и его алкилпроизводных.

6. Водяной пар реагирует с продуктами деструкции алкилфенолов.

\section{ЛИТЕРАТУРА}

1. Р а уд сепп Х. Т., Р аудсепп Х. Э., Тр. Таллинск. политехн. ин-та. Сер. А, № 262,13 (1968).

2. Р а удселп Х. Т., Р а уд сепп Х. Э., Изв. АН ЭССР, Хим. Геол., 17, 149 (1968).

3. Г а в риллов а А. Е., Гон и кбе рг М. Г., Изв. АН СССР, ОХН, вып. 9, 1691 (1961).

4. Гоникбер г М. Г., Л и Г уан -н ян ь, Изв. АН СССР, ОХН, вып. 3, 491 (1961).

5. Schneider P., Kraus M., B ažant V., Coll. Czech. Chem. Comm., 26, 1636 (1961).

6. Schneider P., Kraus M., B aža nt V., Coll. Czech. Chem. Comm., 27, 9 (1962).

7. B e r a nek L., K r a u s M., B a ž a n t V., Coll. Czech. Chem. Comm., 29, 239 (1964).

8. Hansch C., S a l to nsta 11 W., S e tt l e J., J. Amer. Chem. Soc., 71, 943 (1949).

9. Hansch C., S cott C., Keller H., Ind. Eng. Chem., 42, 2114 (1950).

10. Corson B., Tiefenthal H., Nickels J., Heinzelman W., J. Amer. Chem. Soc., 77, 5428 (1955).

11. Ди ми тров Х., Пец ев Н., Докл. Болг. АН, 16, 525 (1963).

12. Шуйкин Н. И., Викторова Е. А., Ли Ши, Караханов Е. А., Изъ. АН CCCP, 11, 2054 (1961).

13. Бал андин А. А., М а рукян Г. М., С ей мович Р. Г., Докл. АН СССР, 141, 616 (1961).

14. Клесмент Й,, Эйзен О., Изв. АН ЭССР, Сер. физ. мат. и техн. н., 14, 147 (1965)

15. Р а удсе п п Х. Т., Р а уд сеп п Х. Э., Тр. Таллинск. политехн. ин-та, Сер. А, № 254 , 35 (1967),

16. Beilsteins Handbuch der organischen Chemie, Bd. VI, Berlin, 1923, S. 561.

17. Р а удс еп п X. Т., В сб́.: Горючие сланшы. Химия и технология, вып. 2, Таллин. 1956, c. 107. 
:HELI RAUDSEPP, H. RAUDSEPP

\section{PROPUUL- JA BUTOULFENOOLIDE TERMILISEST DESTRUKTSIOONIST VEEAURU KESKKONNAS}

Uuriti $o$-isopropüülfenooli, $o$-propüülfenooli, $o$ - ja $p$-butüülfenoolide segu destruktsiooni veeauru keskkonnas temperatuuridel $700 \mathrm{ja} 750^{\circ} \mathrm{C}$. Pōhiliseks reaktsiooniks on fenoolide alküülrühma lagunemine, kusjuures tekivad vastavad metüül- ja etüülfenoolid ning hüdroksübenseen. Peale selle moodustavad $o$-alküülfenoolid bensofuraani ja ta alküüiderivaate. Dehüdroksüleerumine toimub vähemal määral. Alküülfenoolide termiline stabiilsus sôltub alküülrühma ehitusest ja asendist.

\section{HELI RAUDSEPP, H. RAUDSEPP}

\section{A STUDY OF THE THERMAL DESTRUCTION OF PROPYL- AND BUTYLPHENOLS IN THE PRESENCE OF WATER VAPOUR}

The thermal destruction of $o$-propyl-, $o$-iso-propyl-, $o$ - and $p$-butylphenols in the presence of water vapour at temperatures of 700 and $750^{\circ} \mathrm{C}$ has been studied. In these conditions, a cracking of the alkyl group of phenols takes place, and cresols, hydroxybenzene and ethylphenols are formed. The alkyl group and hydroxyl group of $o$-isomers dehydrocyclate, and methylcoumarones and coumarone are formed. The reaction of dehydroxylation takes place to a smaller extent.

The thermal stability of alkylphenols depends on the structure of the alkyl group. 